\title{
Groundwater in Brazil
}

\author{
by Aldo da C. Rebouças
}

Groundwater is increasing in importance in Brazilian water supplies, in part as a response to the growing costs and other constraints in storing and treating surface water and partly because the advantages of groundwater are now better understood. This descriptive review summarizes major groundwater resources and usage in Brazil, and comments upon the need for improved water quality, more training, better legislation and sounder management. (Ed.)

\section{Introduction}

With an area of $8,511,965 \mathrm{~km}^{2}$, Brazil lies between latitudes $5^{\circ} \mathrm{N}$ to $34^{\circ} \mathrm{S}$ and between longitudes $35^{\circ} \mathrm{W}$ and $74^{\circ} \mathrm{W}$ and extends over several climatic zones, ranging from equatorial in the north to temperate in the south. The seasonal distribution of rainfall varies greatly, but most of the country receives an annual average of 1000 to $3000 \mathrm{~mm}$, which results in a significant water surplus. Only a small part of northeastern region is relatively deficient in rainfall (400 to $800 \mathrm{~mm}$ per year, see Fig. 1). The large and dense network of rivers is responsible for an average annual discharge of $177,900 \mathrm{~m}^{3} / \mathrm{sec}$, or $251,000 \mathrm{~m}^{3} / \mathrm{sec}$ if the international tributaries of the Amazon basin are included.
The present population of about 141 million is highly urbanized, with over $66 \%$ living along the eastern coastal region. Large resources of surface water occur in these areas, and surficial deposits and weathered basement rocks provide additional sources of groundwater. The national allocation of water planned for 1990 has been estimated (DNAEE, 1984) at some $10 \mathrm{~km}^{3} / \mathrm{yr}$ for household and public services, $8 \mathrm{~km}^{3} / \mathrm{yr}$ for self-supplied industries, and $16 \mathrm{~km}^{3} / \mathrm{yr}$ for agricultural needs (irrigation, livestock). The total demand corresponds to some 0.6 \% of the surface-water potential.

Groundwater was considered to be a "local" resource in the early phase of its development in Brazil, serving domestic and rural needs through springs, single wells, and small well fields (for general reviews see Rebouças, 1979, and DNPM, 1983). Expanded use for municipal, industrial and irrigation purposes (Fig. 2) has demonstrated that for much of the country the resource is regional in its basin dimensions, and that the hydrological responses of these systems to large areal withdrawals are also regional in extent. Thus, over the past 25 years or so significant attention has been devoted to defining the regional characteristics and appraising the development of major aquifer systems in the northeast and in São Paulo State. These efforts have yielded a great deal of valuable information to guide regional planning, development, and management of the nation's groundwater resources.

The importance of subsurface water to national development is, however, not yet fully appreciated. Its place in the national economy cannot be measured solely by the ratio of groundwater volume withdrawn to surface water withdrawn for public water supply services. For example, despite the benefits of adequate water supply service, in the São Paulo metropolitan area (15 million inhabitants) thousands of uncontrolled private wells provide significant groundwater for hotels, hospitals, residences and industries. These contribute substantially to reducing water charges, particularly in relation to the inflationary prices of the public service. As a rule, most of the inhabitants of the rural areas and suburbs, 908 of industries and almost $50 \%$ of the urban dwellers of Brazil use groundwater.

\section{Groundwater Development}

Brazil coincides almost entirely with the Precambrian platform of South America, which outcrops over about half of the country, with sedimentary basins covering about $40 \%$. Both basement and basins are partly overlain by surficial deposits, mainly unconsolidated sediments, which cover $14 \%$ of the territory.

Groundwater is generally obtained from three types of wells: dug, drilled and driven. The latter two predominate for domestic supplies. About 200,000 deeper wells have been drilled in the last 30 years by municipalities and industrial concerns. Most of these are generally $15 \mathrm{~cm}$ in diameter and less than $100 \mathrm{~m}$ deep; only a small proportion are over $200 \mathrm{~m}$ in depth. Specific capacity ranges from 0.1 to $1.5 \mathrm{~m}^{3} /$ hour $/ \mathrm{m}$. However, in 
the large sedimentary basins there are many wells deeper than $500 \mathrm{~m}$ that reach the best aquifers. Wells in the Paraná and Maranhão basins (some to $2000 \mathrm{~m}$ and with diameters of $76 \mathrm{~cm}$ ) have obtained flows of hundreds or even thousands of $\mathrm{m}^{3} / \mathrm{h}$, with specific capacities ranging from 5.0 to $20.0 \mathrm{~m}^{3} / \mathrm{h} / \mathrm{m}$.

Brazil is a federation of states, and under the national Constitution the responsibility for water matters rests with Federal Government. On a nationwide basis the National Department of Mineral Production (DNPM) of the Ministry of Mines and Energy is responsible for groundwater. Other concerned organizations are state and regional agencies,

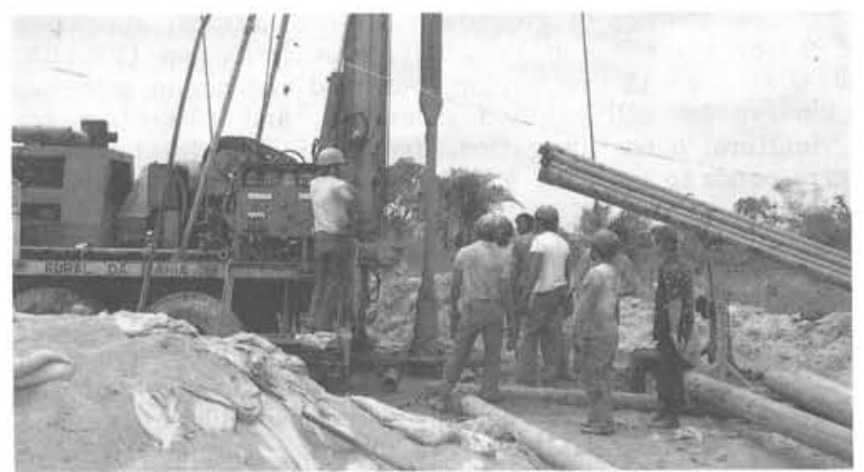

Figure 2: Drilling for water to be used for irrigation in the semi-arid zone, Bahia State.

private organizations, public funding agencies and educational institutions. Although the patterns of surface water resources are generally known and the potentials of surface reservoirs on principal rivers have been extensively appraised, studies of the nation's groundwater resources have been limited (see Fig. 3). These vary from investigations yielding scarcely any groundwater information, through reconnaissance to intensive studies. For most of the country, where there are less than 5 people per $\mathrm{km}^{2}$, there is scarcely any groundwater information.

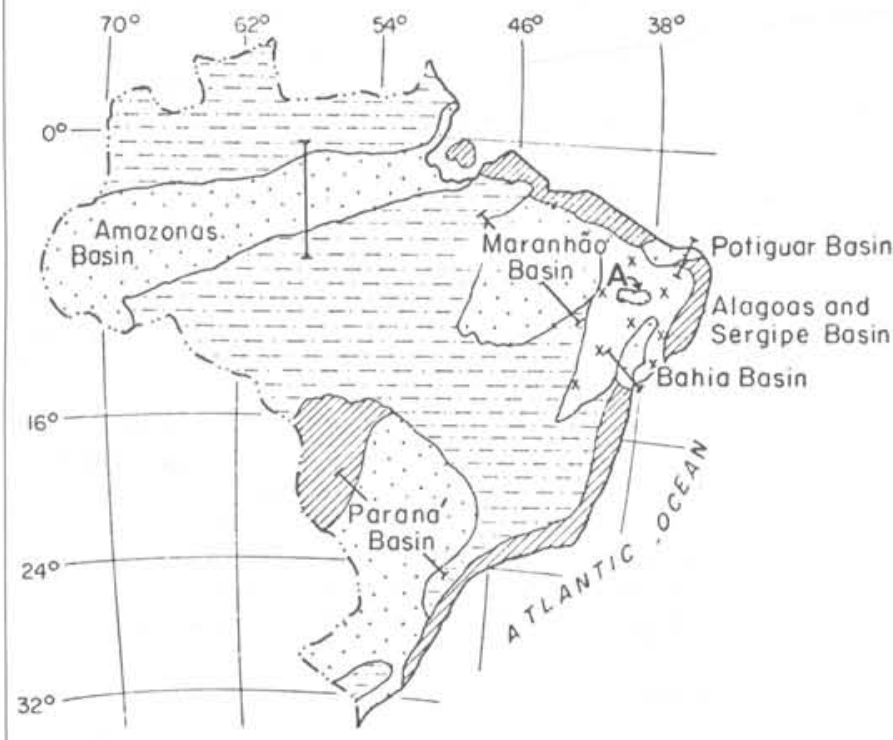

Figure 3: Major hydrogeological divisions in Brazil. Aquifers: surficial (diagonal lines), sedimentary basin (dots), weathered basement (dash-dot), fractured basement (crosses). Lines of sections in Figs. 7 \& 8 indicated. A: Araripe basin. After Rebouças and Cavalcante (1987).
Groundwater studies have focussed on the drought-stricken northeast and the more developed centres where surfacewater quality is impaired or demand exceeds supply, such as São Paulo, Salvador, Recife, Fortaleza and Natal. The continued expansion in the use of groundwater has resulted in an ever-increasing need for skilled professionals in the field of resource evaluation, well technology, and water use and protection.

Courses in groundwater are now offered at ten universities in Brazil. Where there is no formal curriculum in groundwater geology or hydrology, these subjects are included as an important part of the curriculum of allied subjects such as engineering geology, engineering hydrology and public water supply. Graduate degrees (M.S. or Ph.D.) with a major in groundwater geology are available at universities at São Paulo, Recife and Porto Alegre. In the Ground Water Research Center of the Institute of Geosciences of the University of São Paulo, founded in 1984, a wide range of courses in hydrogeology and related areas are taught, and there are now 20 students in master and doctorate-level programs in groundwater geology. Nevertheless training facilities are inadequate to meet current needs, much less the future demands for groundwater specialists.

TABLE 1: Groundwater Reserves in Brazil

$\begin{array}{lccc}\begin{array}{l}\text { Water-Bearing } \\ \text { Formations }\end{array} & \begin{array}{c}\text { Area } \\ \left(1000 \mathrm{~km}^{2}\right)\end{array} & \begin{array}{c}\text { Principal } \\ \text { Aquifer } \\ \text { Systems }\end{array} & \begin{array}{c}\text { Stored } \\ \text { Volume } \\ \left(\mathrm{km}^{3}\right)\end{array}\end{array}$

\begin{tabular}{|c|c|c|c|}
\hline $\begin{array}{l}\text { Fractured } \\
\text { basement rocks }\end{array}$ & 600 & $\begin{array}{l}\text { Fractured rock } \\
\text { zones }\end{array}$ & 80 \\
\hline $\begin{array}{l}\text { Weathered } \\
\text { basement rocks }\end{array}$ & 4,000 & $\begin{array}{l}\text { Weathered rock } \\
\text { mantle and related } \\
\text { fractured zones }\end{array}$ & 10,000 \\
\hline Amazon Basin & 1,300 & Tertiary deposits & 32,500 \\
\hline Maranhão Basin & 700 & $\begin{array}{l}\text { Corda-Grajau Fm } \\
\text { Samambaia Fm } \\
\text { Poti-Piaui Fm } \\
\text { Cabeças Fm } \\
\text { Serra-Grande Fm }\end{array}$ & 17,500 \\
\hline $\begin{array}{l}\text { Potiguar-Recife } \\
\text { Basin }\end{array}$ & 23 & $\begin{array}{l}\text { Barreiras Gr } \\
\text { Jandaíra Fm } \\
\text { Açu-Beberibe Gr }\end{array}$ & 230 \\
\hline $\begin{array}{l}\text { Alagoas-Sergipe } \\
\text { Basin }\end{array}$ & 10 & $\begin{array}{l}\text { Barreiras } \mathrm{Gr} \\
\text { Marituba } \mathrm{Fm}\end{array}$ & 100 \\
\hline Bahia Basin & 56 & $\begin{array}{l}\text { Marizal Fm } \\
\text { São Sebastiao Fm }\end{array}$ & 840 \\
\hline Paraná Basin & 1,000 & $\begin{array}{l}\text { Bauru Gr } \\
\text { Serra Geral Fm } \\
\text { Botucatu Fm } \\
\text { Piramboia Fm }\end{array}$ & 50,000 \\
\hline Surficial deposits & 823 & $\begin{array}{l}\text { Alluvium } \\
\text { Sand dunes } \\
\text { Tertiary deposits }\end{array}$ & 411 \\
\hline
\end{tabular}

TOTAL

111,661

Groundwater conferences and eongresses organized by the Associação Brasileira de Aguas Subterrâneas (ABAS) since 1978 have resulted in a large increase of published papers. The periodicals Revista Aguas Subterrâneas and ABAS Informa provide information on present activities. $\overline{\mathrm{ABAS}}$ has now about 800 members.

Three main aquifer types have been distinguished in Brazil; surficial, deeper ones in regional sedimentary basins, and basement rock aquifers ( $\mathrm{Fig}$. 3). The volumes of water stored in these systems are presented in Table 1, and Figure 4 shows the specific capacities of each (see also Table 2). Total withdrawal from the aquifers is difficult to estimate because most comes from uncontrolled private wells. 


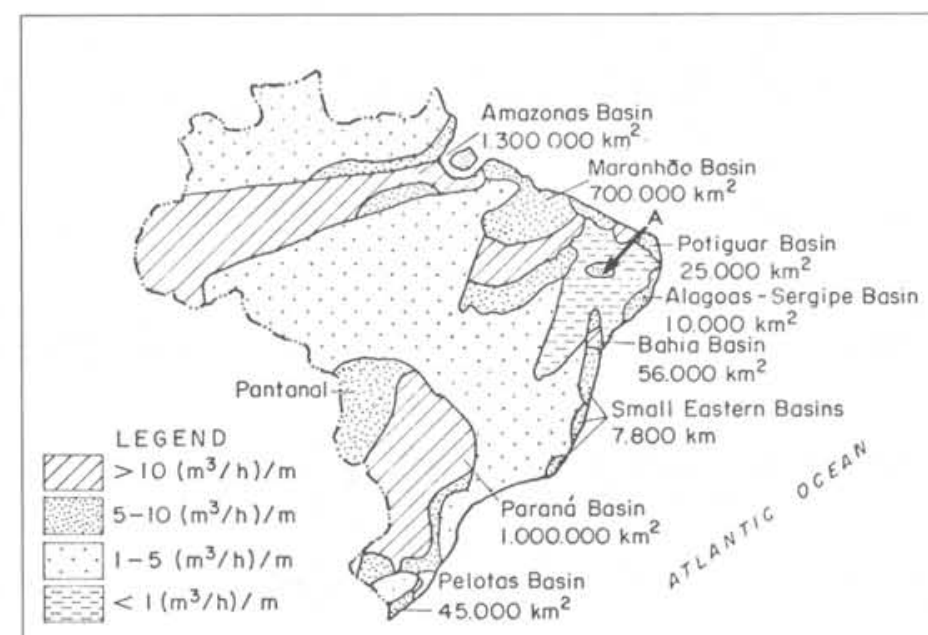

particularly for water supply, industrial use, livestock in rural areas, and small irrigation schemes. Hydrogeological conditions vary, but crystalline rocks with a deeply weathered mantle or cover deposits $(10-50 \mathrm{~m}$ thick) can be distinguished from crystalline rocks with less than $10 \mathrm{~m}$ of weathered or detrital cover. The former comprise about 808 of the Precambrian basement area. Aquifers in fractured basement are now being extensively developed, though as Costa (1986) emphasized, structural and rock mechanic studies are needed in the search for high yielding wells here.

Current studies indicate that major controls are exercised by the rainfall regime and by the physical characteristics of the weathering profiles that affect infiltration and effective porosity below the water table. Chemistry, mineralogy, petrology and structure, of course, play a primary role in weathering reactions, and the age of the land surface is also important, since older surfaces will have been subjected to several climate cycles. Finally, it may be noted that the fractured bedrock may have high transmissivity but low storativity, whereas the weathered overburden, where the clay content varies, will have low to moderate transmissivity but high storativity. Relict vertical structures from the original bedrock may also persist in horizontally layered soil profiles and assist local infiltrations.

\section{Surficial Aquifers}

Surficial aquifers generally occur in unconsolidated clastic sediments. Some excellent aquifers are found in alluvial deposits of the main rivers, and consist chiefly of sand and clay. However, most surficial aquifers occur in coastal sands and dunes associated with Tertiary unconsolidated deposits, less than $100 \mathrm{~m}$ thick. High transmissivity and high yields characterize many of the sand and gravel aquifers, but the latter vary greatly in vertical and lateral directions. Specific capacity ranges from 1 to $5 \mathrm{~m}^{3} / \mathrm{h} / \mathrm{m}$.

Groundwater exploitation has caused significant changes in metropolitan areas such as Belém, São Luiz, Fortaleza, Natal and Maceió. Septic tanks are used in about $50 \%$ of the areas, and all contribute to groundwater contamination. Indeed, pollution problems have now become serious in all types of surficial aquifers of Brazil (Fig. 5). Recent studies (Rebouças, 1975, CETESB, 1984) have shown high nitrate and nitrite contents in almost 758 of the wells in principal urban centers, though total dissolved solids (TDS) are usually less than $100 \mathrm{mg} / \mathrm{l}$.

\section{Basement Aquifers}

Vast areas of Brazil are floored by Precambrian crystalline basement rocks and although associated aquifers are not highly productive, they are of considerable importance,

\section{TABLE 2: Hydrological Parameters for Some Basins}

\section{Maranhảo Basin}

(100 pumping tests, various aquifers)

- Transmissivity: $6 \times 10^{-2}$ to $7 \times$ $10^{-5} \mathrm{~m}^{2} / \mathrm{sec}$

- Storage Coefficient (Rebouças, 1968): $5 \times 10^{-2}$ (unconfined) to $3 \times 10^{-5}$ (confined)

Yield: $20-500 \mathrm{~m}^{3} / \mathrm{h}$

\section{Potiguar Basin}

Açu Sandstone

- Yield: $100-300 \mathrm{~m}^{3} / \mathrm{h}$

- Hydraulic coefficient: $12 \times 10^{-3} / \mathrm{sec}$

- Storage coefficient: $3 \times 10^{-4}$

. TDS: $500 \mathrm{mg} / 1$ (average)

Bahia Basin (Southern part)

- Transmissivity; $5 \times 10^{2}$ to $3 \times$ $10^{-4} \mathrm{~m}^{2} / \mathrm{sec}$

- Storage coefficient: 0.3 to $5 \times 10^{-4}$

TDS: $<300 \mathrm{mg} / 1$, up to $40,000 \mathrm{mg} / 1$
Paraná Basín

Botucatu Aquifer (Data from water wells)

- Yield: from $10-150 \mathrm{~m}^{3} / \mathrm{h}$ (unconfined) to 300 to $1000 \mathrm{~m}^{3} / \mathrm{h}$ (artesian)

Transmissivity: $1.5-7 \times 10^{-3} \mathrm{~m}^{2} / \mathrm{sec}$

- Storage Coefficient: $0.2-0.05$ (unconfined), $10^{-3}$ to $10^{-6}$ (confined)

Basalt (Data from 371 wells -

Hausman, 1966; DAEE, 1974, 1976)

Specific capacity: $3.5 \times 10^{-3}$ to $37.7 \mathrm{~m}^{3} / \mathrm{h} / \mathrm{m}$, mean $0.5 \mathrm{~m}^{3} / \mathrm{h} / \mathrm{m}$

- Depth of wells: $31-190 \mathrm{~m}$ (average $-84 \mathrm{~m}$ )

- Permeability: $10^{-3}-10^{-7} \mathrm{~m} / \mathrm{sec}$ (average $10^{-5} \mathrm{~m} / \mathrm{sec}$ )

- TDS: $<300 \mathrm{mg} / 1$ (Fe to $9.8 \mathrm{mg} / \mathrm{l} ; \mathrm{SiO}_{2}$ to $30 \mathrm{mg} / \mathrm{l}$ )

Baurú-Caiuá formations

Yields: $1.3-80 \mathrm{~m}^{3} / \mathrm{h}$

- Specific capacity: $0.03-6 \mathrm{~m}^{3} / \mathrm{h} / \mathrm{ms}$

. TDS: $<200 \mathrm{mg} / 1$

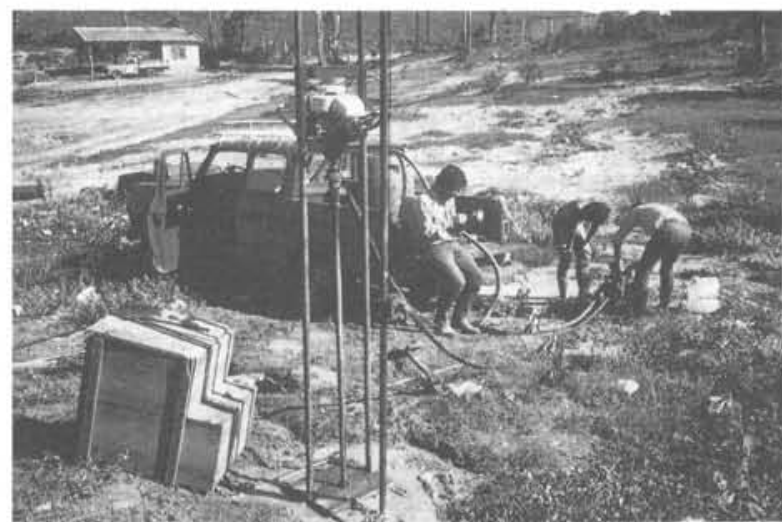

Figure 5: Drilling to monitor groundwater pollution due to industrial wastes, Taubate, São Paulo State.

In deeply weathered areas the vegetation is relatively dense, and annual rainfall exceeds $1000 \mathrm{~mm}$. Hydrolysis, with the aid of carbonic acid and $\mathrm{CO}_{2}$, is probably the dominant mechanism of weathering. The typical weathered profile (Rebouças and Cavalcante, 1987) may be summarized as follows:

- Surficial zone formed by clayey sands, often with evidence of laterization, mostly in the equatorial and tropical climate zone. This massive material ranges from a few metres to $30 \mathrm{~m}$ thick. Hydraulic conductivity is low $\left(10^{-4}\right.$ to $\left.10^{-5} \mathrm{~cm} / \mathrm{sec}\right)$ as is the effective porosity $(0.1$ to 28$)$.

- Friable material formed by disintegrated erystal aggregates and rock fragments, with thickness between 5 and $30 \mathrm{~m}$. Hydraulic conductivity is moderate to high $\left(10^{-3}\right.$ to $10^{-2} \mathrm{~cm}$ per sec), with a moderate porosity (2-5\%).

- Fractured and fissured rock zone a few metres in thickness. Hydraulic conductivity is usually high (locally $10^{-1}$ to $10^{-3} \mathrm{~cm} / \mathrm{sec}$ ).

The amount of water stored in the weathered or detrital basement mantle (Table 1) was evaluated using an average thickness for the saturated aquifer zone of $50 \mathrm{~m}$ and an effective porosity of 38 . Shallow wells dug to depths from a few metres to $20 \mathrm{~m}$ in weathered basement rocks are used extensively in many parts in Brazil, for small domestic and livestock supplies. 
The situation regarding drilled water wells in the decomposed crystalline rocks of the Greater São Paulo metropolitan area may also be quoted (DAEE, 1975). The State Department of Water Supply examined 1,129 wells here, mostly used by industry, and found an average depth of $110 \mathrm{~m}$ (range $50-300 \mathrm{~m}$ ) and an average yield of $7.7 \mathrm{~m}^{3} / \mathrm{h}\left(5-150 \mathrm{~m}^{3} / \mathrm{h}\right)$. The most productive zone is usually situated between 50 and $100 \mathrm{~m}$ in depth, corresponding to the lowest zone of the weathered profile and the fractured zone below. Wells in schist and gneiss have nearly the same average yield, but the latter are an average 208 deeper than the former (Parisot, 1983).

Fractured rock aquifers can be found in denuded igneous, metamorphic and other significantly deformed Precambrian rocks. The storage capacity of unweathered basement rocks is restricted to the interconnected systems of fractures, joints and fissures, such openings being primarily the result of regional tectonic phenomena. The yield and quality from such aquifers in semi-arid zones are commonly poor. A study of the semi-arid zone (Rebouças and Gaspary, 1966, and Rebouças, 1973) indicated an average annual recharge in the basement fractured rock aquifers of about $1-28$ of the average precipitation of $770 \mathrm{~mm} /$ year.

The main task in groundwater exploration in basement areas is to find a fracture pattern with maximum storage capacity. These patterns are often clearly visible in the topography, and aerial photos and satellite imagery are good tools for recognizing major structures. Moreover, surface drainage networks are commonly aligned along fracture systems in the underlying rock (Fig. 6). The frequency of occurrence of productive fractures in crystalline rocks decreases with depth, with the optimal zone considered to be around $30 \mathrm{~m}$. The suggested limit for economic drilling is $60 \mathrm{~m}$.

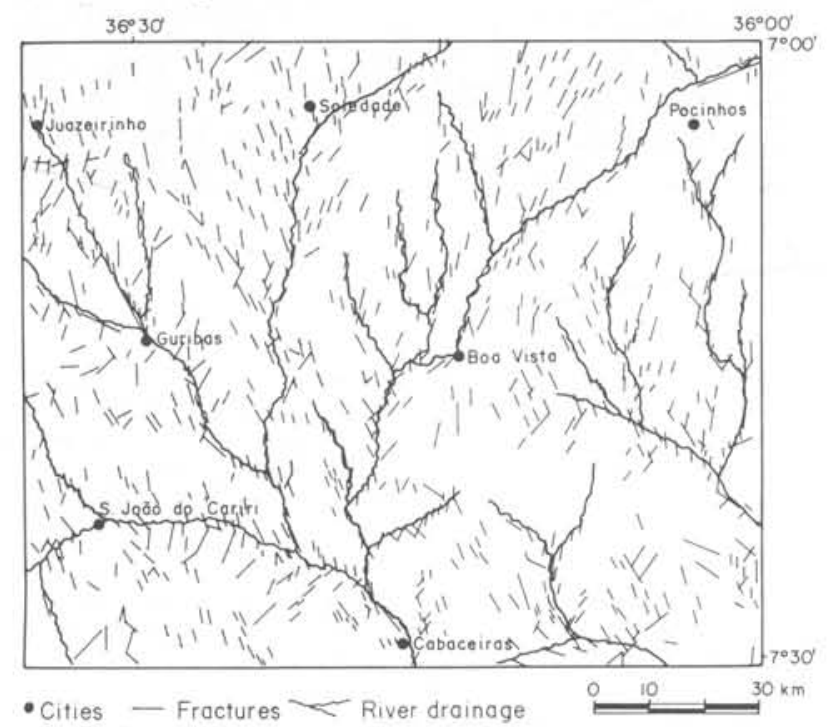

Figure 6: Typical fracturing features and related river drainage in a semi-arid region of Paraíba State, nothereastern Brazil. From Albuquerque (1971).

Rebouças (1975b) reports that about 15,000 wells have been drilled in fractured crystalline rocks in the semi-arid region, of which $92 \%$ were considered successful. The specific capacity of these successful wells is between 1.0 and $0.1 \mathrm{~m}^{3}$ / $\mathrm{h} / \mathrm{m}$. Groundwater quality in the regions underlain by crystalline basement rocks in Brazil tends to be quite variable from place to place and even from season to season. This results from the fact that hard rock aquifer zones are compartmentalized into independent recharge-discharge regimes and climate-topographic features.
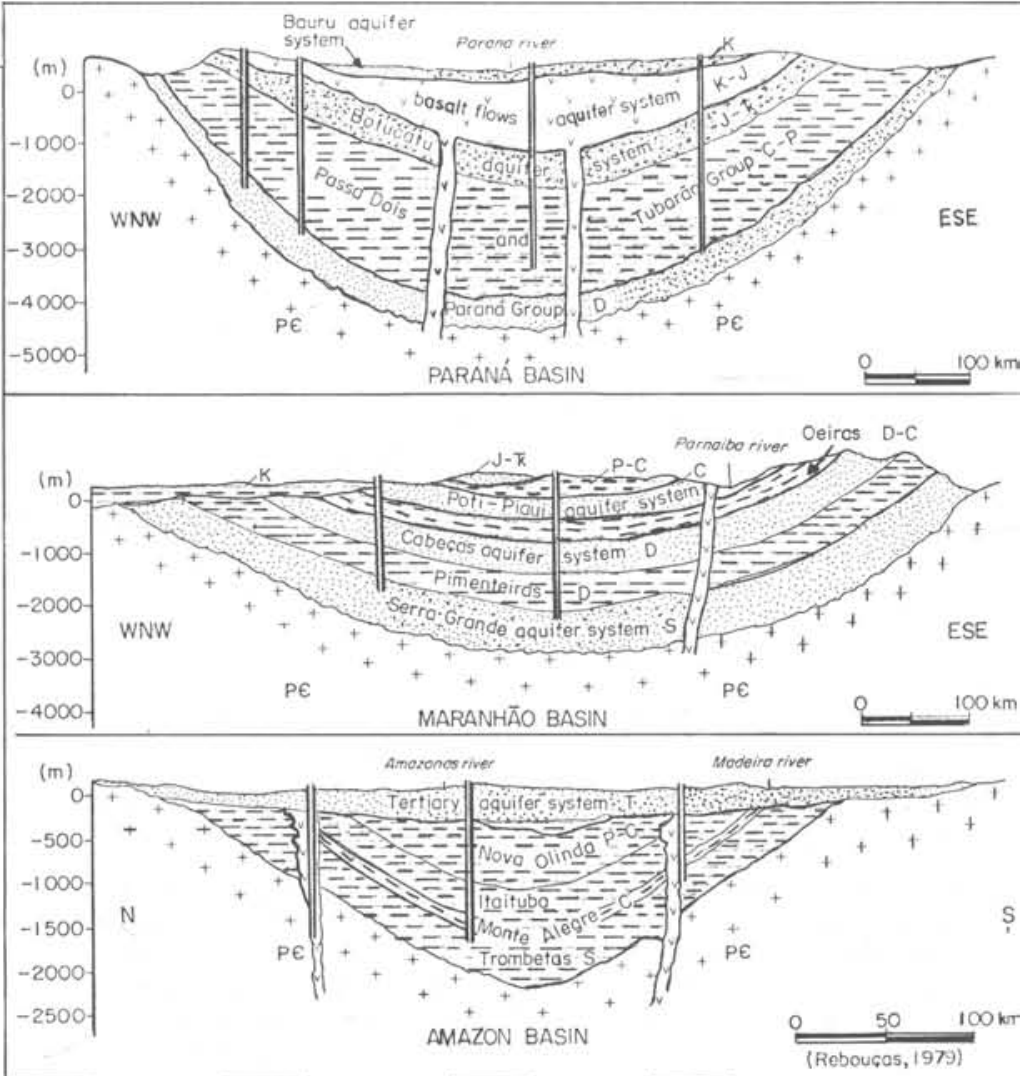

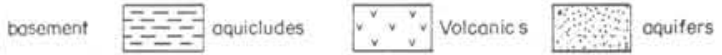

Figure 7: Generalized sections across the Paraná (A), Maranhão (B) and Amazon (C) sedimentary basins. For location see Figure 3. Paired vertical lines show locations of Petrobrás boreholes. Note vertical exaggeration. After Rebouças (1979).

Groundwater quality tends to be best (TDS $<200 \mathrm{mg} / 1$ ) in the regions where average rainfall is more than $1000 \mathrm{~mm} / \mathrm{yr}$. The quality tends to be poor where the average annual rainfall is less than $800 \mathrm{~mm}$. Here evaporation exceeds precipitation, concentrating and accumulating salts in the residual groundwater. In the semi-arid zone, groundwater commonly has TDS $>2000 \mathrm{mg} / 1$ (Cruz and Mello, 1968).

\section{Regional Sedimentary Aquifers}

The sedimentary basins of Brazil $\left(3,165,965 \mathrm{~km}^{2}\right)$ contain chiefly sandstones, shales, limestones and dolomites, with sequences many thousands of metres in thickness (Fig. 3). The most important groundwater basins are the Amazon, Paraná and Maranhão. There are also narrow and discontinuous coastal sedimentary deposits and grabens in the basement rocks. A knowledge of the stratigraphy in these basins is, of course, fundamental to a study of the distribution of the aquifers and the accumulation of water in them. On the whole, younger formations are better waterbearers than older ones and are more extensively used for water supply, because they lie nearer the surface and are less cemented, less compacted, more porous, more easily reached in drilling, and more readily recharged with water from the surface.

\section{The Paraná Basin}

Underlying most of the developed region of Brazil (Minas Gerais, São Paulo, Paraná, Santa Catarina and Rio Grande do Sul states), and extending into eastern Paraguay, northwestern Uruguay and northeastern Argentina is the Paraná Basin (Fig. 7), with a total surface of about $1,600,000 \mathrm{~km}^{2}$. The Brazilian portion, covering about $1,000,000 \mathrm{~km}^{2}$ has a maximum thickness of $5,000 \mathrm{~m}$. The sedimentary sequence (Silurian to Cretaceous) in this intercratonic basin is almost 
undisturbed, with gentle dips towards the center of the basin. Local faults may have served as channels for the extruding basalt flows.

The Paleozoic sediments are not very satisfactory with respect to quantity and quality of their contained water. Among the most important aquifers are the Furnas sandstone of the Devonian Paraná Group, the Aquidauana and Itararé sandy beds of the Lower Permian (Tubarão Group, in part), the Rio Bonito Formation of the Middle Permian part of the Tubarão Group, and the Rio do Rasto Formation of the Upper Permian Passa Dois Group. As a rule, in the central areas of the basin, the water in these sandstones is rather highly mineralized, but within 100 or $200 \mathrm{~m}$ of the surface the quality is generally better except that it is rather hard or rich in sulphurous gas. Paleozoic aquifers are significant only along the eastern, southern and northwestern narrow margins of the Paraná sedimentary basin, where well yields range up to 10 to $50 \mathrm{~m}^{3}$ /hour.

More important as a source of water are Triassic-Jurassic and Cretaceous formations of the Paraná Basin. They are separated by an extensively developed and widespread basaltic package. The Triassic-Jurassic deposits form an aquifer of continental dimensions, the Botucatu aquifer. This extends over $950,000 \mathrm{~km}^{2}$ and has an average thickness of $300-400 \mathrm{~m}$. It is composed of silty and shaly sandstone of fluvial lacustrine origin (the Piramboia Formation) and variegated quartz sandstones accumulated by eolian process under desert conditions (the Botucatu Formation). A thick basaltic package (up to $1,500 \mathrm{~m}$ ) overlies this aquifer, reducing its exposed areas to only $10 \%$ of the total area it underlies.

Situated in a region with abundant surface-water resources, the Botucatu aquifer is almost untapped. Data on water potentials were obtained from almost 100 exploration boreholes drilled for petroleum research and from some 200 water wells. Not surprisingly in view of the great depths it reaches (almost $2000 \mathrm{~m}$ ) and the thick confining basaltic cover, the water stored in the Botucatu aquifer is relatively hot $\left(50-90^{\circ} \mathrm{C}\right)$. About 708 of its total area has artesian conditions. The production cost per cubic metre of water varied from $\$ 0.05$ to $\$ 0.17$ US in 1976 . Considering a discharge of $540 \mathrm{~m}^{3} /$ hour, this represents only 40 \% of the cost of using surface sources (Rebouças, 1976). There has been much discussion of possible exploitation of the Botucatu aquifer (e.g. Leinz, 1953; Gilboa, Mero and Mariano, 1976; Rebouças, 1976).

Basalt flows cover about $1,000,000 \mathrm{~km}^{2}$ of the Paraná Basin. Groundwater occurs within the interflow zones and along cooling joints. Interbedded sediments greatly increase the average porosity of large volumes of rocks. Most commonly the vertical permeability is very small in comparison to the horizontal permeability, indeed in many regions the vertical permeability is so low that separate confined aquifers are formed (Table 2). Some 5000 wells provide ample supply for domestic usage and for small industrial plants.

The Cretaceous is represented in the Paraná Basin by the Baurú-Caiuá formations (Fig. 7). These sandstones, which cover some $315,000 \mathrm{~km}^{2}$ with an average thickness of $100 \mathrm{~m}$, are fairly well cemented, and the water is usually of relatively good quality. About 5,000 wells (mostly $15 \mathrm{~cm}$ in diameter to depths from $<100 \mathrm{~m}$ to several $100 \mathrm{~m}$ ) have been drilled over wide areas of the region. They provide practically all the domestic supplies and many of the small industrial and public supplies.

\section{The Maranhão Basin}

Next in importance as a source of groundwater is the Maranhão Basin, with an area of $700,000 \mathrm{~km}^{2}$ and a maximum thickness of $3,000 \mathrm{~m}$. Strata dip gently towards the center of the basin and are cut by local faults, which as in the case of the Paraná Basin are the loci for diabase dikes (Fig. 7). Among the most important water-bearing formations are the Serra Grande sandstone of Silurian age $(50-700 \mathrm{~m})$, the Devonian Cabeças sandstone $(200-300 \mathrm{~m})$, and the Carboniferous Piaui and Poti sandstones $(200-300 \mathrm{~m})$. These are separated by prominent shaly beds, which also have many sandy beds that yield water, most of which is too salty to be used.

Some 2000 wells penetrate the principal aquifers and furnish supplies for domestic, and industrial usage and irrigation (Table 2). Many are less than $100 \mathrm{~m}$ deep, and only a small proportion are deeper than $300 \mathrm{~m}$. Water quality in these Paleozoic rocks depends on its position in respect to the drainage level, rather than on the formation that contains it. Fortunately, the water up to $1000 \mathrm{~m}$ below the surface is generally of good quality, though rather hard, for domestic usage and irrigation (Table 2).

The Mesozoic deposits of the Maranhão basin yield water in moderate quantities, generally ample for rural domestic uses and for small industrial plants. Existing wells yield as much as 5 to $50 \mathrm{~m}^{3} /$ hour.

\section{The Amazon Basin}

Data on the groundwater of the huge Amazon Basin comes from exploration boreholes drilled for petroleum research. The basin has been filled to $7,000 \mathrm{~m}$, largely with Paleozoic and Cenozoic formations (Fig. 7). The former, mostly finegrained sandstones, outcrop in long narrow areas along both the north and the south sides of the lower Amazon Basin, over about $150,000 \mathrm{~km}^{2}$; some may yield significant supplies of groundwater.

Most of the surface of the Amazon Basin is underlain by Tertiary sediments, which cover about $1,500,000 \mathrm{~km}^{2}$ at an average thickness of $600 \mathrm{~m}$. Most groundwater comes from the Cenozoic, but at Belém, Manaus and Marajó Island deeper wells have been drilled to $60-250 \mathrm{~m}$. Yields vary from 5 to $150 \mathrm{~m}^{3} / \mathrm{h}$. One of the most common types is the dug or Amazon-type well mostly near rivers. Wells of this type have yielded as much as $50-250 \mathrm{~m}^{3} / \mathrm{h}$. TDS are less than $100 \mathrm{mg} / \mathrm{l}$, but the iron content is sometimes up to $15 \mathrm{mg} / \mathrm{l}$. The waters are usually excessively corrosive.

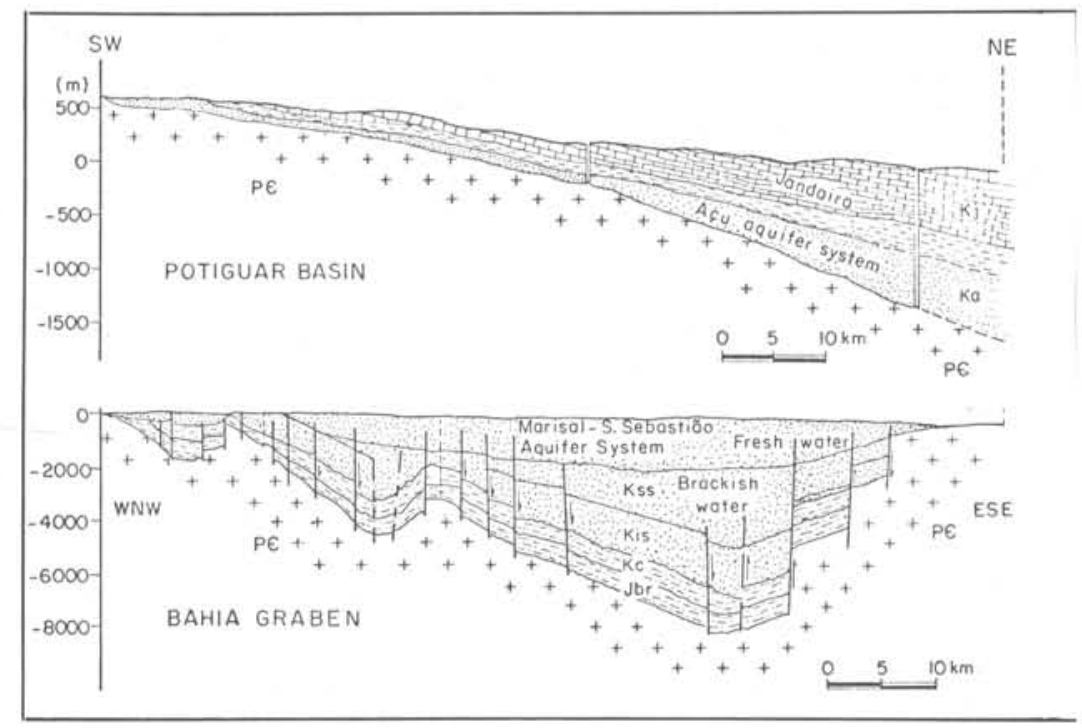

Figure 8: Generalized sections across the Potiguar and Bahia basins. Aquifers (stipple), aquicludes (dash-dot), Precambrian basement (crosses). A: after Rebouças and others (1967), B : after Leite (1963). 


\section{The Northeastern Basins}

Satisfactory supplies of water are available in most of the small sedimentary basins of the northeast region, and in the narrow coastal sedimentary areas. The Araripe Plateau (Chapada) with an area of $11,000 \mathrm{~km}^{2}$ is an immense oasis in the drought region (Fig. 2). About 100 springs issuing from the northeast side of the Chapada yield $4000 \mathrm{~m}^{3} / \mathrm{h}$ (Rebouças and Gaspary, 1966), with TDS less than $100 \mathrm{mg} / 1$. Additional water supplies can be developed from wells in the lowland areas, chiefly along the northeast side of the Chapada. The most important urban centers of this area such as Juazeiro do Norte, Barbalha, Missão Velha and Milagres are supplied by drilled wells, yielding 50 to $150 \mathrm{~m}^{3} / \mathrm{h}$ some of which are artesian. But in general economically viable use of groundwater here is practically non-existent.

\section{The Coastal Basins}

In the relatively narrow and discontinuous coastal basins, large quantities of groundwater have been developed from sand and gravel aquifers, which dip gently and become thicker seawards. The most important aquifers are Cretaceous and Tertiary sandstones, in the Potiguar and AlagoasSergipe basins.

The continental part of the Potiguar Basin (Fig. 8) covers around $22,500 \mathrm{~km}^{2}$. The Cretaceous Açu Sandstone is the most important aquifer, though productive wells here generally exceed $1000 \mathrm{~m}$ depth. In the most important urban centers of the area, such as Mossoró, Areia Branca and Macau, industrial plants and irrigation are supplied from deep artisian wells. These have also been developed in the coastal zone of the Paraíba and Pernambuco states. The depth of the Upper Cretaceous Beberibe aquifer ranges from 100 to $600 \mathrm{~m}$, and the average yield is $80 \mathrm{~m}^{3} / \mathrm{h}$. About $20 \mathrm{~km}$ offshore from the coast line, test wells drilled by Petrobrás yield essentially fresh artesian water from depths of $2,000 \mathrm{~m}$, flowing at a rate of about $150 \mathrm{~m}^{3} / \mathrm{h}$, with temperatures of $82^{\circ} \mathrm{C}$ (Rebouças et al., 1967).

The Upper Cretaceous Jandaíra limestone is the second most important aquifer of the Potiguar Basin. Its total surface is $18,000 \mathrm{~km}^{2}$, and the thickness ranges from 50 to over $300 \mathrm{~m}$ on the continental part. About 1000 wells yield as much as $5-10 \mathrm{~m}^{3} / \mathrm{h}$. Much of their water is, however, slightly salty; average TDS content is $2000 \mathrm{mg} / \mathrm{l}$.

The Bahia Basin (Fig. 8) extends from the eity of Salvador northwards into Pernambuco State. The deposits fill a downfaulted graben in the basement rocks, and cover about $56,000 \mathrm{~km}^{2}$, with thicknesses of 3,000 to $8,000 \mathrm{~m}$. The most developed and widespread water-bearing formations are the Lower Cretaceous São Sebastião and the Upper Cretaceous Marizal sandstones. The water of deep formations is generally rather highly mineralized, and quality depends on its position with respect to the drainage levels rather than on the formation in which it exists. Flowing wells have been developed and, locally, salt water alternates with zones of fresh water. In general, it is possible to develop large quantities of groundwater from sand and gravel in the outcropping zones of the different formations, chiefly in the southern half of the basin (Table 2).

The Tertiary formations of the coastal region from Salvador to São Luiz consist mainly of sand and clay, which overlie Cretaceous formations or basement rocks. Like the Cretaceous, they dip gently seawards, and they include a number of good aquifers, chiefly the beds of sand, which supply many flowing and nonflowing wells. Their water is generally of good quality in the areas located at some distance from the sea.

\section{Conclusions}

Groundwater in Brazil is an important resource for urban, industrial and agricultural developments. There are now no technological limitations to reaching the deeper confined aquifers in Brazil. However, the present water laws are often inadequate, confusing or difficult to apply. The exploitation of groundwater resources, thus, poses three sets of challenges: problems of knowledge, problems related to the legislation to provide compatible development and conservation strategies, and problems related to the selection of ways and means of action.

Increases in exploration, assessment and managment of groundwater resources in Brazil is a necessity if further usage and development is to be carried out wisely. Further research is also required to estimate the effects of human activity, including land use changes on groundwater quality. Finally, there is the problem of informing and educating the public: it is necessary to find appropriate ways and means of disseminating information and of popularizing understanding of the nature of this hidden resource.

Prof. A. da C. Rebouças is Director of the Ground Water Research Center at the University of São Paulo (CEPAS-USP, CP 20899, 01498 São Paulo, Brazil). Trained in Brazil and France, his work covers all aspects of hydrogeology from regional studies to geotechnical aspects, management and economics. $\mathrm{He}$ is President of the Brazilian National Committee for IAH.

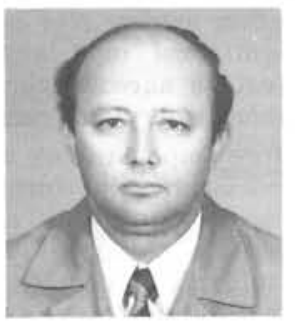

References

Albuquerque, J.P.T., 1971. Inventário Hidrogeologico Básico do Nordeste, Folha 15 - Jaguaribe - SE Brazil. Sudene, Hidrogeologia, no. 32, 1860. ., Recife.

CETESB (Cin Estadual de Teenologin e Saneamento Ambiental - Sศ̃o Paulo), 1984. Qualidade da Ấgua Subterrânea no Estado de São Paulo, 92̧., São Paulo.

Costa, W.D., 1986. Análise dos fatores que atunm no aquifero fissural. Anais do IV Congresso Brasileiro de Águas Subterrâneas. Brasilia, p. 289-302.

Cruz, W.B. and Melo, F.A., 1968. Estudo Geoquímico preliminar das águas subterrâneas do Nordeste do Brasil. Sudene, Hidrogeologia, v. 19, $147 \mathrm{p}$., Recife.

DAEE (Departamento de Águas e Energia Elétrica), 1974. Estudo de Águas Subterrâneas Regino Adm. Atlas, no. 6, v. 4, 245 p., São Paulo.

DAEE (Departamento de Águas e Energia Elétrica), São Paulo, 1975. Estudo de Águas Subterrâneas do Estado de São Paulo. Regiao Adm. 1, Grande São Paulo, v. 1, 220p., São Paulo.

DAEE (Departamento de Águas e Energia Elétrica), São Paulo, 1976. Fstudo de Águas Subterrâneas Regioes Adm. Atlas 7, 8, 9, v. 6, 240p., São Paulo.

DNAEE (Departamento Nacional de Águas e Energia Elếtrica), 1980. Recursos Hídricos do Brasil, Brasília, 350p.

DNAEE (Departamento Nacional de Águas e Ẽnergia Elêtrica), 1984. Disponibilidade Hidrica do Brasil, Brasilia, 258p.

DNPM (Departamento Nacional de Produção Mtineral), 1983. Mapa Hidrogeológico do Brasil na escala $1: 5,000,000$, Brasília.

Gilboa, Y, Mero, F. and Mariano, 1.B., 1976. The Botucatu Aquifer of South America, Model of an untapped continental aquifer. Journal of Hydrology, v. 29, no. 1-2, p. 165-179, The an untapped
Netheriands.

Hausman, A., 1966. Comportamento do Freático nas áreas basílticas do Rio Grande do sul. Boletim Paranaense de Geografia, no. 18-20, p. 177-21 3, Curitiba.

Leinz, V., 1953. Água subterrânea com referência a São Paulo, Ciêneia e Cultura, v. 5, no. 3 , p. 119-120, Såo Paulo.

Leinz, V. and Sallentien, B., 1962. Água subterrânea no Estado de São Paulo e regiōes limitrofes. Sociedade Brasileiro de Geologia, Boletim, v. 11, no. 1, p. 27-36. São Paulo.

Leite, D.C., 1963. Colaboraçao da PETROBRAS no Problema de Águas subterrâneas para o Nordeste. Anais do XvII, Congresso Brasileiro de Geologia, v. 3, p. 24-35, Recife.

Parisot, E.H., 1983. As águas subterrâneas no Centro-Oeste do Municlipio de São Paulo. Características hidrogeológicas e quimicas. Dissertação Mestrado Instituto de Geociências, Universidade de Săo Paulo, $92 \mathrm{p}$.

Rebouças, A. da C. and Gaspary, J., 1966. As íguas subterrâneas do Nordeste, Estimativas Preliminares. Sudene, Hidrogeologia, v. 6, 80p., Recife.

Rebouças, A.C., Manoel Filho, J. and Benoit, H., 1967. Bacia Potiguar, Estudo Hidrogeológico. Sudene, Hidrogeologia, v. 15, 140p., Recife.

Rebouças, A.C., 1968. Características Hidrodinâmicas de alguns aquiferos do Brazil. IV Simposio de Geologia do Nordeste, Sociedade Brasileiro de Geologia, Nucleo SP, Boletim, p. 19-27, Recife.

Rebouças, A.C., 1973. Le probleme de l'eau dans ta zone semi-aride đu Brésil, Evaluation des ressources, orientation pour la mise en valeur. These Université Louis Pasteur de Strasbourg, Strasbourg, 291p.

Reboucas, A.C. 1975日, Oeorrência de nitritos e nitratos nas aquas subterrâneas do Nordeste. VII Simposio Geologia do Nordeste, Fortaleza, 56p.

Rebouças, A. da C., 1975b. Orientation nouvelle pour I'exploration des eaux souterraines du socle erystallin de la zone semi-aride du Brésil. Associacion International Hydrogeologie Memoire, v. 11, p. 41-53, Porto Alegre.

Rebouças, A.C., 1976. Recursos Hiđđrocos subterrâneos da Bacia do Paraná. Análise de Pré-Viabilidade. Tese de Livre Docência. Instituto de Geociêneias, Universidade de São Paulo, 143 p., São Pauto.

Reboucas, A. da C., 1979. Ground water in Brazil. III World Congress on Water Resources, v. ?, p. 3384-3389, Mexico.

Rebouças, A.C. and Cavaleante, I.N., 1987. Hydrogeology of erystalline basement rocks in Technical Publication series no. 232, 54p., London. 